\title{
IMPACT OF FOREIGN DIRECT INVESTMENT (FDI) ON DOMESTIC INVESTMENT IN REPUBLIC OF CROATIA
}

\section{Igor Ivanović}

$\mathrm{PhD}$ student, Juraj Dobrila University of Pula, Faculty of Economics and Tourism "Dr. Mijo Mirković"

Petra Preradovića 1/1, 52100 Pula, Croatia Pješčana Uvala, 4. ogranak broj 25, 52100 Pula e-mail: iggy@pu.htnet.hr GSM: +385958822961

Article info:

Paper category: Review Received: 23.6.2015. Accepted: $5 \cdot 11.2015$. JEL classification: $F_{21}$ 


\begin{abstract}
The aim of this paper is to investigate how foreign direct investment (FDI) affects domestic investment in the Republic of Croatia. More precisely, the general purpose of this study is to determine the impact of net inflow of foreign capital on domestic investment in order to gain a clearer picture about the sensitivity and efficiency of domestic investment. After parsing domestic investment and FDI in Croatia, according to Croatian Bureau of Statistics and the Croatian National Bank, a historical overview of their movement from 1995 to 2014 was analyzed. In the following an overview and comparison of studies from around the world which deal with similar topic was made. In the empirical part; domestic gross fixed capital formation, changes in domestic stocks, net FDI and GDP growth rate was used as variables. Quarterly time series data ranging from the $Q_{1} 2001$ to $Q_{4} 2014$ were processed with the subset VAR (vector autoregressive) econometric model. The results shows that FDI have negative influence on domestic investment in the Republic of Croatia with time lag.
\end{abstract}

\title{
Keywords:
}

foreign direct investment; gross investment; crowding out/in effect; subset VAR; investment efficiency 


\section{INTRODUCTION}

As present times are marked by the aftermaths of the global economic crisis from $2007 / 08$, affected countries are seeking to find way out recession. In order neutralize the negative effects that crisis has caused they look for the most appropriate and the most optimal economic growth policy. To achieve this goal these countries (including Republic of Croatia) should focus on the determinants of economic growth that could be affected in relatively short time period. Todaro and Smith (2012) ${ }^{1}$ state that the components of economic growth of primary importance in a country are:

- capital accumulation (which include all new investments),

- population growth and

- technological progress.

Population growth and technological progress can not be affected in a relatively short time period while accumulation of capital and investments can. Taking it into consideration it is evident that investments could be the key to the way out of country's recession. Furthermore, investments in one country may be domestic and foreign. Due to existence of multinational companies together with the effects of globalization, investments that cross the boundaries of countries are increasingly common case (e.g. according to Hecksher-Ohlin theory and corresponding theorems of international exchange, the difference in price of production factors can cause the off shoring of production factors from one country to another (Babić, Pufnik, Stručka, 2001 $\left.{ }^{2}\right)$. Size and importance of such investments cannot be overlooked because they can reach significant percentages of GDP in some countries. Investments coming from abroad in a particular country can be grouped into three main groups, namely: portfolio investments, foreign direct investments (FDI) and other investments, which include loans and borrowings (Sisek, 2005) ${ }^{3}$. The share of portfolio investments is less than $10 \%$ of the total value of companies in which is invested, and they are used mainly for profit to investors with no aspirations for management of companies. Next two, FDI and other investments suggest investing in new facilities/ activities (such as greenfield investment) or taking over and connecting foreign with local companies (among them are brownfield investment). Motives of foreign companies for FDI in a country may be different like exploitation of natural resources, concurring new markets, improving production efficiency and strategically motivated investments (Sisek, 2005).

1 Michael P. Todaro and Stephen C. Smith, Economic development, 11th edition, (United States of America, Addison Wesley, 2012: 14,0).

2 Ante Babić, Andreja Pufnik and Tihomir Stučka, "The theory and reality of FDI in the world and in transition countries with special reference to Croatia," Review of Croatian national bank 9 (2001: 2).

3 Boris Sisek, "Foreign direct investment in Croatia - Causes of failure," Proceedings of the Faculty of Economics in Zagreb 3 (2005: 90). 
Accordingly, the analysis and understanding how internal and external factors affects the investments are extremely valuable in shaping policies of economic growth in any country. Since Republic of Croatia is a small, open and export-oriented economy with a long-term external imbalances with high sensitivity to external influences, studying the impact of FDI as external factor on domestic investment as a factor of economic growth can have several benefits. Correspondingly, focus of this study will be the impact of foreign direct investments (FDI) on domestic investment in the Republic of Croatia. The impact of FDI on investment can be positive, neutral or negative. Positive impact will occur if invested FDI increases total investment for sum is greater than FDI themselves. If invested FDI increases total investment exactly for the height of its amount neutral effect will occur. Finally, if the domestic investment decreases regardless the FDI inflow a negative effect will occur. With the advent of negative effect of FDI on domestic investment Crowding out effect occurs. Conversely, with the advent of positive effect of FDI on domestic investment Crowding in effect occurs.

There are numerous studies that deal with the relationship of FDI and investment, and these articles often analyze more countries or regions together and perform comparison, classification, panel analysis etc. Accordingly, there are studies that analyze the situation in Croatia comparing it with other countries, mostly from the region (countries in southeast Europe, countries in transiton or Balkan countries). A part of aforementioned referent studies is analyzed in the third chapter of this Article. Also, there are several studies that study or FDI or investments in Croatia, but there are few studies dealing with the influence of FDI on domestic investment in Croatia. In the next chapter historical analysis of FDI and domestic investment in Croatia can be found.

\section{DOMESTIC INVESTMENT AND FOREIGN DIRECT INVESTMENT (FDI) IN CROATIA}

In Croatia according to the methodology of Croatian bureau of statistics (CBS) gross investment as part of GDP i.e. domestic investment ${ }^{4}$ consists of gross fixed capital formation and changes in stocks ${ }^{5}$ as shown in equation (1). Gross fixed capital formation consists of investments into new fixed capital formation, costs of transactions of existing fixed assets and additions to the value of non-produced assets. Changes in stocks are calculated for working-progress and finished goods, stocks of commercial goods in stores, and stocks of raw material, spare parts, etc.

$$
\text { Domestic investment }=\text { Gross fixed capital formation }+ \text { Changes in stocks }
$$

4. Different authors domestic investment appoint as Gross capital formation, Private investment, Gross investment, Gross domestic investment etc. In further writing domestic investment term will be used. 
On Figure 1. annual movement of domestic investment in Croatia from 1995 to 2014 is shown. The graph shows how Gross fixed capital formation makes the most of domestic investment (over 90\%). It is also evident that domestic investment have a constant trend of growth from 1995 to 2008 and that during those 13 years domestic investment grew about 5 times. After the global economic crisis in 2007 domestic investment have downward trend during the six years from 2008 to 2014 and they have fallen about $4,0 \%$.

Figure 1.: Domestic investment in Croatia

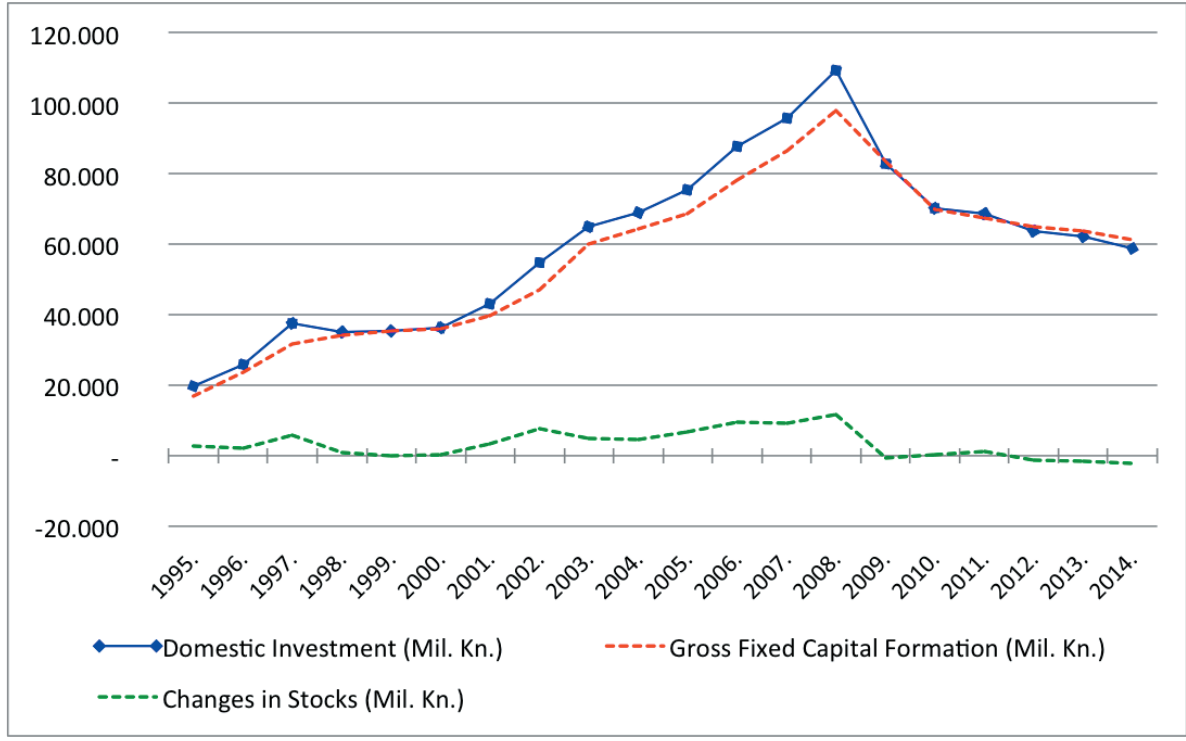

Source: Author's calculation from Croatian bureau of statistics (CBS).

As already mentioned above in theory, investment is one important component of economic growth. In order to assess whether the investments precisely should be encouraged to achieve desired economic growth, it is good to further analyze existing investments in the country to get more clearer picture of them and their "behavior". One common method of measuring Investment efficiency in the is variable known as ICOR (Incremental Capital-Output Ratio) that came from Harrod-Domar's growth model (Lovrinčević, Mikulić, Marić, 2004) ${ }^{6}$. According to the Harrod-Domar's model, growth rate of each economy is the relationship between savings rate and capital coefficient where ICOR is equal to the capital coefficient. ICOR is by definition, the relationship between investment rate (the share of investment in GDP) and growth rate of real GDP (Lovrinčević, Mikulić, Marić, 2004), as shown in equation (2).

6 Željko Lovrinčević, Davor Mikulić and Zdravko Marić, "Investment efficiency and FDI - Old story, new circumstances," Economic Review, 55 (2004: 5). 


$$
I C O R=\frac{\text { Gross fixed capital formation as percentage of GDP }}{\text { Growth rate of real GDP }}
$$

It should be noted that an important flaw of ICOR concept is that it does not allow interpretation of investment efficiency in the case of negative real GDP growth rates. For the analysis of investment efficiency in countries with negative real GDP growth rates the average value of ICOR for a longer time period is defined. In the research from 2004, Lovrinčević et.al have calculated for Croatia among other countries in the period from 1994 to 2002 that the average ICOR value was 4.9. Since this paper examines the impact of FDI on domestic investment in Croatia from 2001 to 2014, the average ICOR value of 14.2 for the same period is calculated. ICOR values for Croatia are shown in Table 1 . Since lower ICOR value means that the investments are more efficient and vice versa, and taking into account only ICOR indicator it can be concluded that investment in Croatia were more efficient from 1994, to 2002, than from 2001 to 2014 .

Table 1: Average real GDP growth rates, average share of investment as percentage of GDP and ICOR in Croatia

\begin{tabular}{|l|r|rr|}
\hline \multicolumn{1}{|c|}{ Republic of Croatia } & $\mathbf{1 9 9 4}^{-\mathbf{2 0 0 2}}$ & 2001-2014 \\
\hline Average real GDP growth rates & 4.3 & & 1.6 \\
Average share of of investment & 21.2 & & 22.2 \\
as percentage of GDP & 4.9 & & 14.2 \\
ICOR & & & \\
\hline
\end{tabular}

Source: Lovrinčević et.al (2004): 8, and author's calculation.

Foreign direct investment (FDI) were often used in the theoretical and empirical work of economists after World War II, and especially after the large growth of international financial flows occurred between the 1980's and 1990's (Babić, Pufnik, Stručka, 2001). When residents of foreign countries are investing in domestic country such investments are known as inbound FDI. In cases where domestic residents are investing in foreign countries such investments are known as outbound FDI. Finally, difference of inbound and outbound FDI gives net FDI as shown in equation (3). Net FDI shows exactly how much net capital has entered in the country.

Net FDI = Inbound FDI - Outbound FDI

Croatia after its independence in 1991 was affected by the civil war that ended in 1995 and it is logical that in this period was not attractive to foreign investors due to high risk. Evidence for this fact is visible in Figure 2. where FDI in Croatia are shown in the period from 1995 to 2014. The graph shows that FDI grew with fluctuations from 1995 to 2008 and after the global crisis they have sharply dropped by over $60 \%$. In 2014 a significant increase of inbound and outbound FDI is evident. 
Figure 2.: Foreign direct investment (FDI) in Croatia

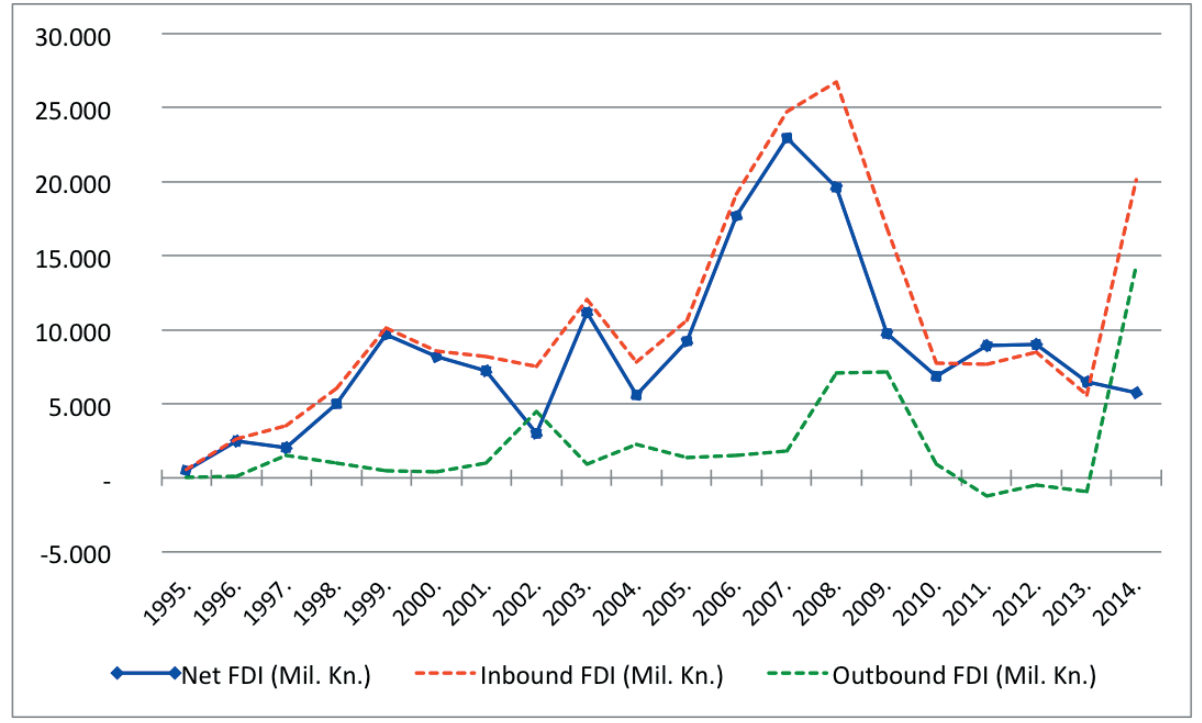

Source: Author's calculation from Croatian national bank (CNB).

Since FDI in global economy are the most important form of international business activity (Derado, 2013) ${ }^{7}$ and investment is a key factor of economic development, analysis of the impact of FDI on domestic investment is theoretically justified. If we compare the net FDI and domestic investment from 1995 to 2014 in Croatia as shown in the Figure 3. it can be seen that FDI amounted to an average of $13.6 \%$ of domestic investment in that period and that their trends are going in similar directions. Since the size of FDI reaches just over a tenth of domestic investment, it is expected that FDI do not have strong and significant impact on domestic investment in Croatia. In order to gain a clearer insight into the relation of FDI and investment a comparative analysis of studies that deal with similar topics is made in the next chapter.

7 Dražen Derado, "Determinants of Foreign direct investment in transition economies and evaluation of their potential in Croatia," Institute for Public Finance, Selected translations ISSN 1847-7445 No. 17/13 (2013: 1). 
Figure 3.: Net FDI and domestic investment in Croatia

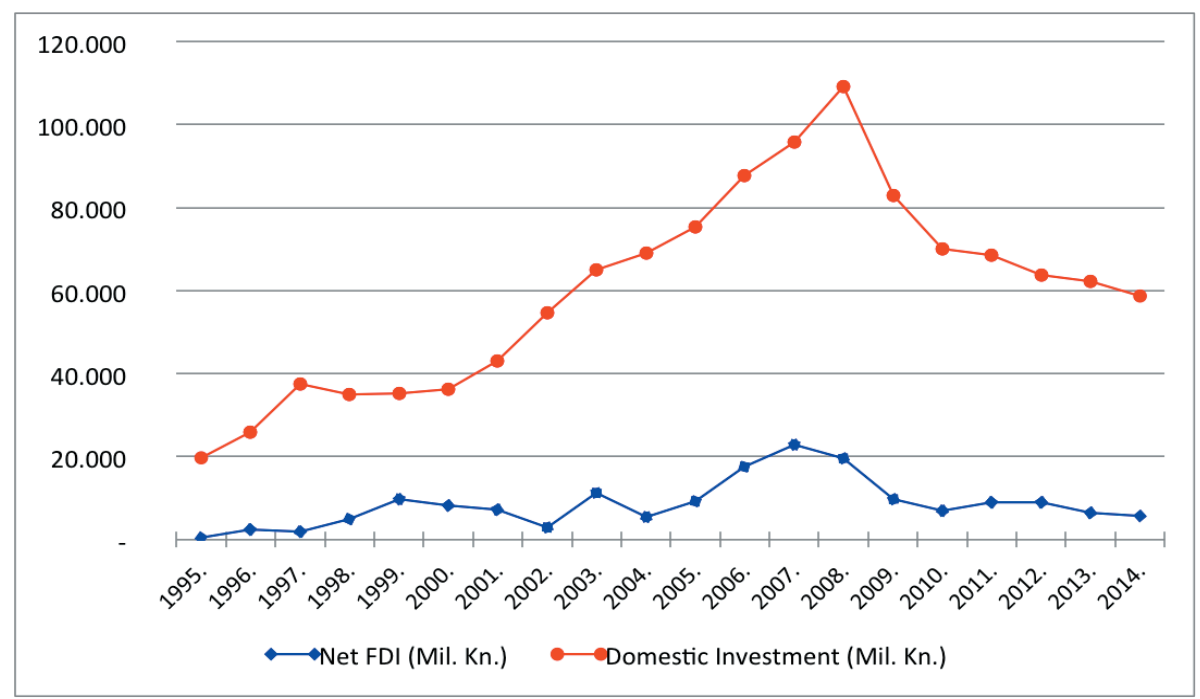

Source: Author's calculation from Croatian national bank (CNB) and Croatian bureau of statistics (CBS).

\section{COMPARATIVE ANALYSIS OF STUDIES THAT DEAL WITH THE SAME TOPIC}

In third section of this paper comparative analysis of papers from around the world that deal with the influence of FDI on domestic investment are presented. The review will begin with a paper of Agosin and Mayer ${ }^{8}$ from 2000 where they assesses the extent to which foreign direct investment in developing countries crowds in or crowds out domestic investment. They have developed a theoretical model of investment which is run for three developing regions (Africa, Asia and Latin America) and they have test it with panel data for the period 1970-1996 and the two subperiods 1976-1985 and 1986-1996. They have included variables such as FDI to GDP ratio, investment to GDP ratio and growth of GDP in this model. The results indicate that in Asia - but less so in Africa - there has been strong crowding in of domestic investment by FDI; by contrast, strong crowding out has been the norm in LatinAmerica. They have generally concluded that the effects of FDI on domestic investment are by no means always favourable and that simplistic policies toward FDI are unlikely to be optimal. The main conclusion that emerges from this analysis is that the positive impacts of FDI on domestic investment are not assured.

For group of 25 transition countries in Central and eastern Europe excluding Bosnia and Herzegovina and FR Yugoslavia in 2001 Krkoska ${ }^{9}$ was looking for rela-

8 Manuel R. Agosin and Ricardo Mayer, "FOREIGN INVESTMENT IN DEVELOPING COUNTRIES, Does it Crowd in Domestic Investment?" UNCTAD/OSG/DP/146 (2000: 1-20).

9 Krkoska Libor, Foreign direct investment financing of capital formation in central and eastern Europe. (London: European Bank for Reconstruction and Development, Working paper No. 67, 2001: 1-19). 
tion between Foreign direct investment (FDI) and Gross fixed capital formation with other sources of capital formation as well. In his research he applied Zellner's Seemingly Unrelated Regression (SUR) method as a system of two simultaneous equations for 1989 - 2000 period using annual data. Variables he used were Gross fixed capital formation, Retained earnings, Domestic credit, State subsidies, Capital market financing, Foreign credit, Foreign direct investment (FDI), Privatisation revenues, Real interest rate, Stock market liquidity, Accession dummy, Natural resources dummy and EBRD transition indicator. The results showed that FDI, domestic credit and local capital markets are all important financing sources for capital formation, with FDI having a greater impact than domestic credit and capital market financing.

In 2005 Lovrinčević et.al ${ }^{10}$ investigated how foreign capital inflow affect national savings, domestic investments and balance of payments of countries in transition in central and eastern Europe. They made analysis of panel data for 11 countries in transition. Annual data were included in the panel from 1993 to 2002. The variables used in analysis where domestic investment, national savings, total gross inflow of foreign capital, gross FDI inflows, gross inflow of foreign portfolio investment, gross inflow of other foreign investment (foreign loans) and real GDP growth. Taken as a whole, inflow of foreign capital in the transition countries have had the effect of encouraging ("crowding-in effect") of domestic investment. FDI proved to be also significant in explaining domestic investment activity in transition countries, but lower intensity and less significance than others.

Within the Working paper of the European Central Bank Mileva ${ }^{11}$ in 2008 published its research that studies the effect of FDI, foreign loans and portfolio flows on domestic investment in Bulgaria, Croatia, Czech Republic, Estonia, Hungary, Latvia, Lithuania, Macedonia (FYR), Poland, Slovak Republic, Romania, Albania, Armenia, Belarus, Georgia, Kazakhstan, Kyrgyz Republic, Moldova, Russian Federation, Tajikistan, Ukraine and Uzbekiistan. For the period 1995 - 2005 annual data were incorporated in static and dynamic panel techniques to assess mentioned relation. Empirical results have shown that FDI flows have caused small investment spillover effect in economies which have completed the transition process or are in final stages. In ten CIS countries and Albania FDI have crowded in domestic investment.

Selvanathan and Tang ${ }^{\mathbf{1 2}}$ have investigated the causal link between FDI, Domestic Investment, and Economic Growth in China. In 2008 they have included quarterly time-series data for above mentioned variables in the period from 1988 to 2003

10 Željko Lovrinčević, Davor Mikulić and Zdravko Marić, "Foreign capital inflow - Influence on national savings, domestic investments and balance of payments of countries in transition in central and eastern Europe," Ekonomski pregled, 56 (3-4) (2005: 163-184).

11 Mileva Elitza. THE IMPACT OF CAPITAL FLOWS ON DOMESTIC INVESTMENT IN TRANSITION ECONOMIES. (Frankfurt am Main, European Central bank, Working paper No. 871, 2008: 1-32).

12 Tang Sumei, E.A.Selvanathan, S. Selvanathan, "Foreign Direct Investment, Domestic Investment, and Economic Growth in China," United Nations - WIDER Research paper No. 2008/19 (2008: 1-15). 
in multivariate VAR system with error correction model (ECM). The results show that there is a single-directional causality from FDI to domestic investment and to economic growth. Rather than crowding out domestic investment, FDI is found to be complementary with domestic investment. Thus, FDI has not only assisted in overcoming shortage of capital, it has also stimulated economic growth through complementing domestic investment in China.

Linkages between FDI, Domestic investment and Economic growth have been examined in Malaysia by Lean and $\operatorname{Tan}^{13}$ in 2010. These three variables are cointegrated in the long-run in this study. Annual time series data over a forty year period from 1970 to 2009 were used and Vector autoregressive (VAR) model is estimated. The empirical results of this study are showing that an increase of FDI will bring positive impact to the domestic investment. In other words, FDI crowds in domestic investment and there appears complementary effect from FDI to domestic investment.

Direct and indirect impact of FDI on domestic investment in India are studied in 2010 by Prasanna ${ }^{14}$. Prasanna covered 16 year period from 1991-92 to 2006-07 and he included variables inflow of FDI, real GDP, real GDP growth rate, and gross domestic investment into UNCTAD (1999a) multiple determination model with lags. This study finds that the direct impact of FDI inflows on domestic investment in India is positive but the indirect impact is 'neutral' on the domestic investment in the long run. The study finds no evidence that the increase in domestic investment due to FDI inflows is greater than the amount of the FDI inflows in India.

Bayraktar and Yalta ${ }^{15}$ in 2011 sought to provide evidence on the dynamic interactions among FDI, private domestic investment and public domestic investment in Turkey. They investigated period from 1970 to 2009 using annual data incorporated into multivariate VAR framework. Their findings indicate that there is no long-run relationship between FDI, public investment and private investment, indicating the poor contribution of FDI to the Turkish investment path. The lack of interaction between FDI and domestic investment, which impedes the contribution of FDI to economic growth from capital accumulation channel, questions the benefits of FDI.

Possible effects of FDI on a recipient economy are studied in 2011 by Jurcic ${ }^{16}$ et.al. The paper analyzes FDI inflows and effects in three selected countries, namely Croa-

13 Hooi Hooi Lean and Bee Wah Tan. "Linkages between Foreign direct investment, Domestic investment and Economic growth in Malaysia," Persidangan Kebangsaan Ekonomi Malaysia ke V (PERKEM V) (2010: 48-57).

14 N. Prasanna, "Direct and Indirect Impact of Foreign Direct Investment (FDI) on Domestic Investment (DI) in India," J Economics, 1(2) (2010: 77-83).

15 Saglam B. Bayraktar, Yalta A. Yasemin, "Dynamic linkages among Foreign direct investment, Public investment and Private investment: Evidence from Turkey," Applied Econometrics and International Development Vol. 11-2 (2011: 71-82).

16 Ljubo Jurčić, Vlatka Bilas and Sanja Franc, "The effects of FDI on the recipient country," The $5^{\text {th }}$ International Scientific Conference "Entrepreneurship and Macroeconomic Management: Reflections on the World in Turmoil" (2011: 1). 
tia, Hungary and Ireland. The starting hypothesis is that initially positive FDI effects in fact turn into negative effects in the long run. Annual data from 1992 to 2009 are used and the FDI effects are analyzed in three phases: (1) the inflow of FDI, (2) the use of reinvested earnings, which both have positive effects, and (3) transferring earnings and sometimes even capital from the recipient country which has negative effect on the balance of payment and lowers gross national product. The common feature of all three economies is that they have received large amounts of FDI at certain periods of time and experienced positive effects from those inflows in the short term. In the long run, large inflows of FDI were not sustained and positive effects failed to materialize.

Next study from 2012 which was made by Hider ${ }^{17}$ tries to find out the relationship of FDI and domestic investment in Pakistan. FDI, financial market development and GDP growth rate are taken as independent variables and domestic investment as independent variable in the ARDL model.ARDL cointegration technique and its error correction model are applied to check the long run and short run relationships. Annual data has been taken in the period from 1972 to 2010 . The results show that the long run and short run relationships exist in the model. FDI, financial market development and economic growth have the positive and significant impact on the domestic investment. So, results prove that FDI has complementary effect on the domestic investment in Pakistan. Financial market development and economic growth play a positive role in enhancing the domestic investment.

Business Start-up Regulations and the complementarity between Foreign and Domestic Investment have been investigated by Munemo ${ }^{18}$ in 2014. He took data about domestic investment, FDI, foreign ownership, cost of business start up, days to start a business, rule of law, inflation rate, GDP growth, price of investment, real GDP per capita and total population in 138 world countries. The model he used is estimated with the Arellano-Bond dynamic Generalized Method of Moments (GMM) two-step panel estimator using annual data over the full sample period (2000 to 2010). Results obtained from different model specifications show that lowering the cost of entry regulation increases the positive impact of FDI on total domestic investment. The results also indicate that FDI crowds out domestic investment in countries with entry regulation above a certain level (mostly poor countries). The central contribution of this paper is its examination of business entry regulations and how they impact the relationship between FDI and domestic investment.

The answer to the question does FDI crowd in or out domestic investment sought Kamaly ${ }^{19}$ in 2014 . He studied 16 emerging countries over a 3o-year period from $197^{8}$ to 2010 , taking the FDI and domestic investment as variables. He

17 Mahmood Haider, "Foreign Direct Investment-Domestic Investment Nexus in Pakistan," Middle-East Journal of Scientific Research 11 (2012: 1500-1507).

18 Jonathan Munemo, "Business Start-up Regulations and the Complementarity between Foreign and Domestic Investment," Perdue School of Business, Salisbury University (2014: 1-25).

19 Ahmed Kamaly, "Does FDI Crowd in or out Domestic Investment? New Evidence from Emerging Economies," Modern Economy, 5, Published Online in SciRes (2014: 391-400). 
grouped all individual country regression in one system of equations as well. This system of equations is estimated using 2 SLS panel data models. Estimation results have shown that the effect of FDI on domestic investment is country specific. In most countries, on impact, FDI has a positive and significant effect on domestic investment. Taking the total or the long-term effect of FDI on domestic investment, there is evidence that in most of the countries included in the sample, FDI has a neutral effect on domestic investment where there is a one-to-one relationship between FDI and total investment. Crowding in or crowding out effect of FDI on domestic investment is only found in few countries. This indicates that the rule is the neutrality of FDI on domestic investment and the exception is otherwise (whether crowding in or out).

(1) Positive impact of FDI on domestic investment can be found in research of Krkoska for 25 transition countries in Central and eastern Europe; in Lovrinčević et.al research for 11 European countries; in Mileva's research for 25 European an CIS countries; Tang's research for China; Lean and Tan's research for Malaysia; Bayraktar research for Turkey; and Hider's research for Pakistan.

(2) Neutral impact of FDI on domestic investment can be found in research of Prasanna for India; and in reseach of Kamaly for 16 emerging countries.

(3) Negative impact of FDI on domestic investment can be found in Agosin and Mayer's research for three developing regions; Jurčić et.al research for Croatia, Hungary and Ireland; and in Munem's research for 138 world countries.

\section{DATA, MODEL SPECIFICATIONS AND METHODS}

This paper primarily analyzes the possible effects of net FDI on the domestic investment in Croatia. Accordingly, the main goal of this section is to investigate the effects of real net FDI as percentage of real GDP changes on real domestic gross fixed capital formation as percentage of real GDP and real domestic changes in stocks as percentage of real GDP. For this purpose a subset VAR (vector autoregressive) model is estimated. Before defining the subset VAR model, a brief analysis of the time series included in the model was made. Data of four variables are observed on a quarterly basis from March 2001 till December 2014. Time series data span from 2001 because the Croatian national bank has no published quarterly data for the FDI in previous years. All data are seasonally adjusted using Arima - X 12 method. Data are retrieved from the Croatian Bureau of Statistics (CBS) ${ }^{20}$ official website and the Croatian National Bank's (CNB) ${ }^{21}$ official website. Variables used in subset

\footnotetext{
20 "Regular Publications," Republic of Croatia - Croatian Bureau of Statistics (CBS), accesed March 15 , 2015, http://www.dzs.hr.

21 "Statistical survey," Croatian national bank, accesed March 15, 2015, http://www.hnb.hr/statistika/ statisticki_pregled/hı_.xlsx.
} 
VAR model are:

(1) Real domestic Gross fixed capital formation as percentage of real GDP, (RINV_ FK)

(2) Real domestic changes in Stocks as percentage of real GDP, (RINV_ZAL)

(3) Real GDP Growth Rate, (RGDPGR) and

(4) Real (net) FDI as percentage of real GDP, (RFDI_RGDP).

Before defining the subset VAR model it is necessary to examine the degree of integration of time series since it is known that models with non-stationary series can lead to wrong conclusions and problems. To do so, the Augmented Dickey-Fuller (ADF) test, Phillips-Perron (PP) test and Kwiatkowski-Phillips-Schmidt-Shin (KPSS) stationarity test are performed. In Table (2., 3. and 4.) results of all three unit root tests are presented.

Table 2.: Augmented Dickey-Fuller (ADF) stationarity test results

\begin{tabular}{|c|c|c|c|c|}
\hline \multicolumn{5}{|c|}{ In level } \\
\hline & \multicolumn{2}{|c|}{ Constant } & \multicolumn{2}{|c|}{ Constant and trend } \\
\hline Variable & Test statistic & $\mathrm{p}$-value & Test statistic & $\mathrm{p}$-value \\
\hline RINV_FK & -1.80797 & 0.3771 & -2.35976 & 0.4 .009 \\
\hline RINV_ZAL & -0.71562 & $0.84,11$ & -2.24908 & 0.4615 \\
\hline RGDPGR & -1.66382 & 0.4498 & -2.39252 & 0.3834 \\
\hline RFDI_RGDP & $-1.54,305$ & 0.5118 & -1.75029 & 0.7288 \\
\hline \multicolumn{5}{|c|}{ First difference } \\
\hline & \multicolumn{2}{|c|}{ Constant } & \multicolumn{2}{|c|}{ Constant and trend } \\
\hline Variable & Test statistic & $\mathrm{p}$-value & Test statistic & $\mathrm{p}$-value \\
\hline RINV_FK & $-2.03 \circ 4,6$ & 0.2738 & $-2.43 \circ 37$ & 0.3636 \\
\hline RINV_ZAL & $-8.375^{24}$ & 0.00000 & -8.315 & 0.00000 \\
\hline RGDPGR & $-4 \cdot 74185$ & 0.00006 & -4.69192 & 0.00067 \\
\hline RFDI_RGDP & -2.85608 & 0.05067 & -2.87595 & 0.1704 \\
\hline
\end{tabular}

Source: Author's calculation. 
Table 3.: Phillips-Perron (PP) stationarity test results

\begin{tabular}{|c|c|c|c|c|}
\hline \multicolumn{5}{|c|}{ In level } \\
\hline & \multicolumn{2}{|c|}{ Constant } & \multicolumn{2}{|c|}{ Constant and trend } \\
\hline Variable & Test statistic & $\mathrm{p}$-value & Test statistic & $\mathrm{p}$-value \\
\hline RINV_FK & $-1.75^{6} 5^{8}$ & 0.3977 & -1.72944 & 0.7244 \\
\hline RINV_ZAL & -4.1506 & 0.0018 & $-5 \cdot 7175^{3}$ & 0.0001 \\
\hline RGDPGR & -1.79597 & 0.3786 & -2.6996 & 0.241 \\
\hline RFDI_RGDP & $-1.57^{8} 55$ & 0.4865 & -1.69997 & 0.7377 \\
\hline \multicolumn{5}{|c|}{ First difference } \\
\hline & \multicolumn{2}{|c|}{ Constant } & \multicolumn{2}{|c|}{ Constant and trend } \\
\hline Variable & Test statistic & $\mathrm{p}$-value & Test statistic & $\mathrm{p}$-value \\
\hline RINV_FK & $-5 \cdot 5694.1$ & 0.00000 & -6.07366 & 0.00000 \\
\hline RINV_ZAL & $-12.4,336$ & 0.00000 & -12.2338 & 0.00000 \\
\hline RGDPGR & -7.61099 & 0.00000 & $-7.5^{3} 5^{31}$ & 0.00000 \\
\hline RFDI_RGDP & -5.30169 & 0.00000 & -5.30288 & 0.0003 \\
\hline
\end{tabular}

Source: Author's calculation.

Table 4.: Kwiatkowski-Phillips-Schmidt-Shin (KPSS) stationarity test results

\begin{tabular}{|c|c|c|c|c|c|c|c|c|}
\hline \multicolumn{9}{|c|}{ In level } \\
\hline & \multicolumn{4}{|c|}{ Constant } & \multicolumn{4}{|c|}{ Constant and trend } \\
\hline Variable & $\begin{array}{r}\text { Test } \\
\text { statistic }\end{array}$ & $1 \%$ & $5 \%$ & $10 \%$ & $\begin{array}{r}\text { Test } \\
\text { statistic }\end{array}$ & $1 \%$ & $5 \%$ & $10 \%$ \\
\hline RINV_FK & $0.234444^{3}$ & 0.726 & $0.47^{\circ}$ & $0.35^{1}$ & 0.232843 & 0.213 & 0.149 & 0.121 \\
\hline $\begin{array}{l}\text { RINV_ }_{-} \\
\text {ZAL }\end{array}$ & 0.83928 & 0.726 & $0.47^{\circ}$ & $0.35^{1}$ & 0.205964 & 0.213 & 0.149 & 0.121 \\
\hline RGDPGR & 0.636102 & 0.726 & 0.470 & $0.35^{1}$ & 0.086905 & 0.213 & 0.149 & 0.121 \\
\hline $\begin{array}{l}\text { RFDI } \\
\text { RGDP }\end{array}$ & $0.6555 \circ 9$ & 0.726 & $0.47^{\circ}$ & $0.35^{1}$ & 0.176249 & 0.213 & 0.149 & 0.121 \\
\hline \multicolumn{9}{|c|}{ First difference } \\
\hline & \multicolumn{4}{|c|}{ Constant } & \multicolumn{4}{|c|}{ Constant and trend } \\
\hline Variable & $\begin{array}{r}\text { Test } \\
\text { statistic }\end{array}$ & $1 \%$ & $5 \%$ & $10 \%$ & $\begin{array}{r}\text { Test } \\
\text { statistic }\end{array}$ & $1 \%$ & $5 \%$ & $10 \%$ \\
\hline RINV_FK & 0.454867 & 0.726 & $0.47^{\circ}$ & $0.35^{1}$ & 0.0834316 & 0.213 & 0.149 & 0.121 \\
\hline $\begin{array}{l}\text { RINV }_{-} \\
\text {ZAL }\end{array}$ & 0.10182 & 0.726 & $0.47^{\circ}$ & $0.35^{1}$ & $0.06884,09$ & 0.213 & 0.149 & 0.121 \\
\hline RGDPGR & 0.0701622 & 0.726 & $0.47^{\circ}$ & $0.35^{1}$ & 0.0686311 & 0.213 & 0.149 & 0.121 \\
\hline $\begin{array}{l}\text { RFDI } \\
\text { RGDP }\end{array}$ & 0.11417 & 0.726 & $0.47^{\circ}$ & $0.35^{1}$ & 0.0554165 & 0.213 & 0.149 & 0.121 \\
\hline
\end{tabular}

Source: Author's calculation.

Given the results two conclusions arise:

(1) the series of (RINV_FK), (RGDPGR) and (RFDI_RGDP) are integrated of or$\operatorname{der} \mathrm{I}(1)$, i.e. their first differences are stationary; 
(2) the (RINV_ZAL) is integrated of order I(o), i.e. it is stationary in levels. Variable (RINV_ZAL) was questionable since ADF test using Schwartz criteria has shown that RINV_ZAL is not stationary using constant and constant with trend. PP test has shown that RINV_ZAL is stationary using constant and constant with trend. Furthermore KPSS test has shown that generally RINV_ZAL is not stationary. Visual inspection of variable has shown that RINV_ZAL might be stationary but with a structural brake. Therefore, Perron unit root test for a variable with structural brake is performed. The test indicates that if constant is used variable is stationary while if trend is included then test results shows that RINV_ZAL is not stationary. However, using the constant and trend together the results indicate that RINV_ZAL is stationary. According to all so far mentioned and based on the results of all tests together with visual inspection of variable, it can be concluded that RINV_ZAL is stationary in level which leads to use of the stationary subset VAR model. Therefore, all other variables are differenced once in order to become stationary.

Based on these assumptions a stationary subset VAR model is estimated shown in equation (4):

$$
y_{t}=A_{1} y_{t-1}+\cdots+A_{p} y_{t-p}+\cdots+C D_{t}+u_{t}
$$

where $y_{t}=\left(y_{t t}, \ldots, y_{K t}\right)$ is vector of $K$ exogenous variables, $D t$ is a vector of deterministic terms (including constant and specified dummy variables), $u_{t}$ is $K$-dimensional vector of residuals while $A$ and $C$ are matrices of parameters of the model ${ }^{22}$.

The vector of endogenous variables includes differenced variable of real domestic Gross fixed capital formation as percentage of real GDP, real domestic changes in stocks as percentage of real GDP, differenced variable of real GDP Growth Rate, (RGDPGR) and differenced variable of real (net) FDI as percentage of real GDP, while the vector of deterministic variables includes constant and several impulse dummy variables due to structural brakes ${ }^{23}$.

Using Top-Down (TD) sequential elimination algorithm which starts from the last regressor in the equation a subset VAR model is estimated. This algorithm checks if deleting the last regressor in the equation improves the criterion value. For this purposes the SC (Schwarz Criteria) criterion is used. If deleted regressor improves the criterion value it is eliminated, otherwise it is maintained. After that step, the second last regressor is checked and so forth. The sequence of this procedure depends on the order of the variables in the model and thereby in the equation. After that, diagnostic tests of the estimated subset VAR model were conducted such as: LM test for autocorrelation, Doornik and Hansen test for non-normality, Lutkepohl test for non-normality, Jarkue-Bera test for non-normality, Arch test and Multivariate Arch test for volatility in the residuals. The results of performed tests suggest that a subset VAR model is evaluated appropriately. All the results of diagnostic tests are

22 The Gretl and JMulTi econometric softwares are used for the multiple time series analysis 
presented in the Appendix 1 . The following is a display of Variance decomposition of forecast errors and impulse response functions.

\section{Variance decomposition of forecast errors}

variance decomposition shows the relative share of individual variables in explaining the variation of other variables in future periods (Bahovec, Erjavec, 2009) ${ }^{24}$. In the following text the forecast error variance decomposition is done from estimated subset VAR model (Table 5.).

Table 5.: Orthogonal variance decomposition of forecast errors

\begin{tabular}{|c|c|c|c|c|}
\hline \multicolumn{5}{|c|}{ Variance decomposition of RINV_FK } \\
\hline Horizon (quarters) & RINV_FK & RINV_ZAL & RGDP_GR & RFDI_RGDP \\
\hline 2 & 0.90 & 0.10 & 0.00 & 0.00 \\
\hline 4 & 0.90 & 0.10 & 0.00 & 0.00 \\
\hline 6 & 0.70 & 0.09 & 0.04 & 0.16 \\
\hline 8 & 0.67 & 0.10 & 0.04 & 0.19 \\
\hline 10 & 0.66 & 0.11 & 0.05 & 0.19 \\
\hline \multicolumn{5}{|c|}{ Variance decomposition of RINV_ZAL } \\
\hline Horizon (quarters) & RINV_FK & RINV_ZAL & RGDP_GR & RFDI_RGDP \\
\hline 2 & 0.00 & 1.00 & 0.00 & 0.00 \\
\hline 4 & 0.00 & 0.98 & 0.00 & 0.02 \\
\hline 6 & 0.00 & 0.97 & 0.00 & 0.03 \\
\hline 8 & 0.00 & 0.96 & 0.00 & 0.04 \\
\hline 10 & 0.00 & 0.95 & 0.00 & 0.05 \\
\hline \multicolumn{5}{|c|}{ Variance decomposition of RGDPGR } \\
\hline Horizon (quarters) & RINV_FK & RINV_ZAL & RGDP_GR & RFDI_RGDP \\
\hline 2 & 0.00 & 0.03 & 0.97 & 0.00 \\
\hline 4 & 0.14 & 0.03 & 0.84 & 0.00 \\
\hline 6 & 0.14 & 0.03 & 0.83 & 0.00 \\
\hline 8 & 0.14 & 0.03 & 0.80 & 0.03 \\
\hline 10 & 0.14 & 0.03 & $0.7^{8}$ & 0.05 \\
\hline \multicolumn{5}{|c|}{ Variance decomposition of RFDI_RGDP } \\
\hline Horizon (quarters) & RINV_FK & RINV_ZAL & RGDP_GR & RFDI_RGDP \\
\hline 2 & 0.05 & 0.01 & 0.01 & 0.94 \\
\hline 4 & 0.07 & 0.04 & 0.04 & 0.85 \\
\hline 6 & 0.08 & 0.08 & 0.04 & 0.80 \\
\hline 8 & 0.08 & 0.09 & 0.04 & 0.79 \\
\hline 10 & 0.08 & 0.12 & 0.04 & 0.76 \\
\hline
\end{tabular}

Source: Author's calculation.

24. Vlasta, Bahovec and Nataša, Erjavec (2009) Introduction to econometric analysis, l. edition (Zagreb: Element 2009: $\left.346-35^{1}\right)$. 
Note: Cholesky ordering: dRINV_FK, RINV_ZAL, dRGDP_GR, dRFDI_RGDP, "d" indicates first difference.

The results indicate that FDI has affected the variability of gross fixed capital formation with $0 \%$ after first 4 quarters, $16 \%$ after 6 quarters, and finally $19 \%$ after 10 quarters. GDP growth rate had no significant impact on the variability of Gross fixed capital formation. Changes in stocks have affected the variability of gross fixed capital formation on average $10 \%$ through the whole period of 10 quarters.

Gross fixed capital formation, GDP growth rate and FDI had no significant impact on the variability of changes in stocks.

Gross fixed capital formation has affected the variability of GDP growth rate with $\circ \%$ after 2 quarters and later $14 \%$ after 10 quarters. Changes in stocks and FDI had no significant impact on the variability of GDP growth rate.

Gross fixed capital formation and GDP growth rate had no significant impact on the variability of FDI. Changes in stocks had no significant impact on the variability of FDI after 8 quarters but after 10 quarters they have affected the variability of FDI with $12 \%$.

\section{Impulse response functions}

impulse response test shows the reactions of individual variables to changes in other variables of one standard deviation in the short and long term (Bahovec, Erjavec, 2009) ${ }^{25}$. In the following text the orthogonal impulse responses decomposition are shown (Figure 4.).

Figure 4.: Accumulated subset VAR orthogonal impulse responses with

$$
\text { efron (- - ) and hall (...) with 95\% confidence intervals }
$$
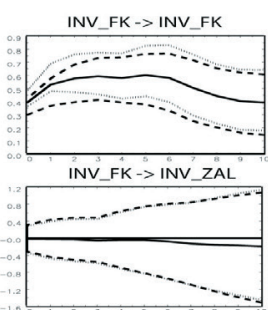

INV_FK -> GDPGR

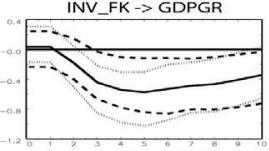

INV_FK $\rightarrow$ FDI

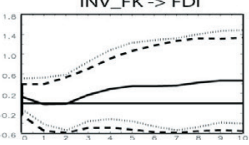

Source: Author's calculation

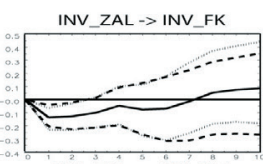

INV_ZAL $\rightarrow$ INV_ZAL

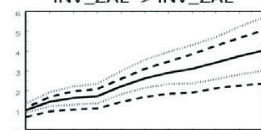

INV_ZAL $>$ RGDPGR

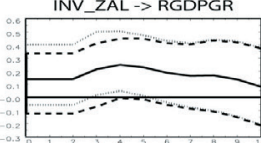

INV_ZAL $>$ FDI

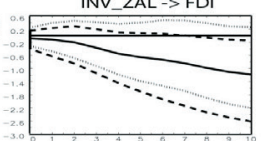

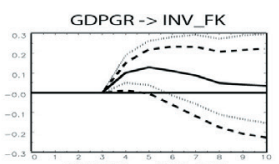

GDPGR $\rightarrow$ INV_ZAL

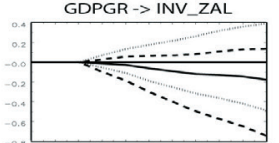

GDPGR $>$ GDPGR

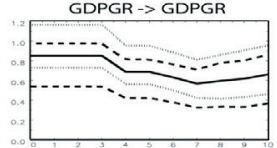

GDPGR $->$ FDI

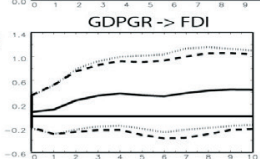

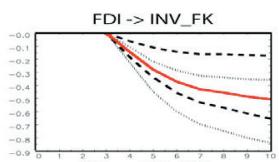

FDI $\rightarrow$ INV_ZAL

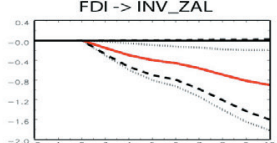

FDI $>$ GDPGR

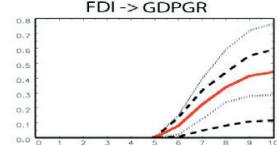

FDI $\rightarrow$ FDI

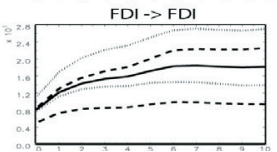

25 Bahovec and Erjavec, Introduction to econometric analysis, (2009: 346 - 351). 
Third graph in first row suggests that shock in GDP growth rate will cumulatively affect the increase in gross fixed capital formation where in the first three quarters will have no effect. Fourth graph in first row shows that shock in FDI will cumulatively affect by reducing the gross fixed capital formation where in the first three quarters will have no effect. Third graph in second row shows that shock in GDP growth rate will cumulatively affect by reducing the changes in stocks where in the first two quarters will have no effect. Fourth graph in second row shows that shock in FDI will cumulatively affect by reducing changes in stocks where in the first two quarters will have no effect. Fourth graph in third row shows that shock in FDI will cumulatively affect the increase in GDP growth rate where in the first five quarters will have no effect.

If we look at the impulse responses of shocks of domestic investment (gross fixed capital formation and changes in stocks) on the FDI we obtain the following results. First graph in the fourth row shows that shock in gross fixed capital formation will cumulatively affect the increase in FDI. Second graph in the fourth row shows that shock in changes in stocks will cumulatively affect by reducing the FDI.

Generally the results of impulse responses correspond to the results of variance decomposition.

It is necessary to emphasize the fact that this analysis does not take into account all the variables that may affect domestic investment, so this model and these conclusion should be taken carefully.

\section{CONCLUSION}

Croatia is a small, open and export-oriented economy with a long-term external imbalances with high sensitivity to external influences and every major impact of foreign/external factors can have a significant effect on its macroeconomic variables. The objective of this paper is to empirically investigate influence of foreign capital inflow known as net foreign direct investment (FDI) on domestic investment in Republic of Croatia. The analysis showed that FDI size were in average $13.6 \%$ of domestic investment from 1995 to 2014. After the performed tests on time series of four variables (FDI, gross fixed capital formation, changes in stocks and GDP growth rate) stationary subset VAR (vector autoregressive) model is selected as the most appropriate for influence assessment. The tests results generally show that the FDI has affected the reduction of domestic investment in the Croatia with time lag, but on the other hand the FDI has affected increase in GDP growth rate with time lag. This study is a good starting point for further and more detailed studies in the future which will over time be more relevant and more precise as time series data will be extended. Taking all into consideration; ICOR coefficient and the results of subset VAR model, we can conclude that the efficiency of domestic investment fell compared to previous years and that FDI leads to a decrease in domestic investment i.e. Crowding-out 
effect occurs. Results of this study are consistent with a Agosin and Mayer's; Jurcic et.al; and Munem's studies. This study, as well as most other studies has limitations such as short period of time being studied, a relatively small number of variables and the fact thatVAR model does not include the exogenous variables. 


\section{REFERENCES}

Agosin, Manuel R. Mayer, Ricardo, "Foreign investment in developing countries", Does it Crowd in Domestic Investment?" UNCTAD/OSG/DP/146 (2000): 1-20

Babić Ante, Pufnik Andreja, Stučka Tihomir, "The theory and reality of FDI in the world and in transition countries with special reference to Croatia"; Review of Croatian national bank 9 (2001): 1-27

Bahovec, Vlasta, Erjavec, Nataša, "Introduction to econometric analysis", 1. edition, (Zagreb: Element, 2009)

Bayraktar, Saglam B. Yasemin, Yalta A., "Dynamic linkages among Foreign direct investment, Public investment and Private investment: Evidence from Turkey", Applied Econometrics and International Development Vol. 11-2 (2011): 71-82

Croatian bureau of statistics, Statistical Yearbook of the Republic of Croatia (2014): 210

Croatian national bank, "Statistical survey", accesed March 15, 2015. http://www.hnb.hr/statistika/ statisticki_pregled/hı7.xlsx

Derado Dražen, "Determinants of Foreign direct investment in transition economies and evaluation of their potential in Croatia", Institute for Public Finance, Selected translations ISSN 1847-7445 No. 17/13 (2013): $1-29$

Haider, Mahmood, "Foreign Direct Investment-Domestic Investment Nexus in Pakistan", Middle-East Journal of Scientific Research 11 (2012): 1500-1507

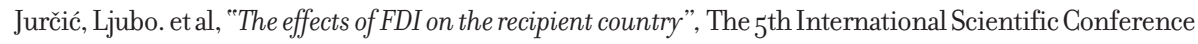
"Entrepreneurship and Macroeconomic Management: Reflections on the World in Turmoil" (2011): 1-17

Kamaly, Ahmed, "Does FDI Crowd in or out Domestic Investment? New Evidence from Emerging Economies", Modern Economy, 5, Published Online in SciRes (2014): 391-4,00

Lean, Hooi Hooi. Tan, Bee Wah, "Linkages between Foreign direct investment, Domestic investment and Economic growth in Malaysia", Persidangan Kebangsaan Ekonomi Malaysia ke V (PERKEM V) (2010): $4^{8-}-57$

Libor, Krkoska, "Foreign direct investment financing of capital formation in central and eastern Europe", London: European Bank for Reconstruction and Development, Working paper No. 67, (2001)

LovrinčevićŽeljko, et al, "Investment efficiency and FDI - Old story, new circumstances”, Economic Review, 55 (2004): $1-4.3$

Lovrinčević, Željko, et al, "Foreign capital inflow - Influence on national savings, domestic investments and balance of payments of countries in transition in central and eastern Europe", Ekonomski pregled, 56 (3-4) (2005): 163-184

Mileva, Elitza, "The impact of capital flows on domestic investment in transition economies", Frankfurt am Main, European Central bank, Working paper No. 871, (2008)

Munemo, Jonathan, "Business Start-up Regulations and the Complementarity between Foreign and Domestic Investment", Perdue School of Business, Salisbury University (2014): 1-25

Prasanna, N. ,"Direct and Indirect Impact of Foreign Direct Investment (FDI) on Domestic Investment (DI) in India", J Economics, 1(2) (2010): 77-83

Republic of Croatia - Croatian Bureau of Statistics (CBS), "Regular Publications", accesed March 15, 2015. http://www.dzs.hr 
Sisek, Boris, "Foreign direct investment in Croatia - Causes of failure", Proceedings of the Faculty of Economics in Zagreb $3(2005): 89$ - 108

Sumei, Tang. Selvanathan, E.A., Selvanathan, S., "Foreign Direct Investment, Domestic Investment, and Economic Growth in China", United Nations - WIDER Research paper No. 2008/19 (2008): 1-15

Todaro Michael P. and Smith Stephen C., "Economic development", United States of America: Addison Wesley, (2012) 


\section{APPENDIX 1: Model statistics and the results of diagnostic tests}

\section{VAR MODEL STATISTICS}

Endogenous variables: d_RINV_FK_dı, RINV_ZAL_dı, d_RGDP_GR_dı, d_ RFDI_RGD_dı.

Exogenous variables:

Deterministic variables: $\mathrm{d}_{1}, \mathrm{~d}_{2}, \mathrm{~d} 3, \mathrm{~d}_{4}, \mathrm{CONST}$

Endogenous lags: $\quad 4$

Exogenous lags: $\quad 0$

Sample range: $\quad$ [2002, Q2, 2014, Q3], T = 50

Log Likelihood: $\quad-3.335847 \mathrm{e}+02$

Determinant (Cov): $\quad$ 7.329306e+oo

AIC: $\quad 2.991881 \mathrm{e}+00$

FPE: $\quad 2.002815 \mathrm{e}+01$

SC: $\quad 3.947892 \mathrm{e}+00$

HQ: $\quad 3.355936 \mathrm{e}+\mathrm{oo}$

LM-TYPE TEST FOR AUTOCORRELATION with 4 lags

Reference: Doornik (1996), LM test and LMF test (with F-approximation)

LM statistic: $\quad 7^{1} \cdot 5^{8} 5^{2}$

p-value: $\quad 0.2407$

df: $\quad 64.0000$

LMF statistic not computed for subset model.

TESTS FOR NONNORMALITY

Reference: Doornik \& Hansen (1994)

joint test statistic: $\quad 11.8804$

p-value: $\quad 0.1566$

degrees of freedom: $\quad 8.0000$

skewness only: $\quad 10.3198$

p-value: $\quad 0.0354$

kurtosis only: $\quad 1.5605$

p-value: $\quad 0.8159$

Reference: Lütkepohl (1993), Introduction to Multiple Time Series Analysis, zed, p. $15^{3}$

joint test statistic: $\quad 10.77^{31}$

p-value: $\quad 0.2149$

degrees of freedom: $\quad 8.0000$

skewness only: $\quad 9.2899$

p-value: $\quad 0.054^{2}$ 
kurtosis only: $\quad 1.4832$

p-value: $\quad 0.8296$

JARQUE-BERATEST

$\begin{array}{lllll}\text { variable } & \text { teststat } & \mathrm{p}-\text { Value }\left(\mathrm{Chi}^{\wedge}{ }_{2}\right) & \text { skewness } & \text { kurtosis } \\ \text { u1 } & 3.7^{3} 95 & 0.154{ }^{2} & 0.6075 & 2.4354 \\ \text { u2 } & 1.6615 & 0.4357 & 0.4398 & 3.1539 \\ \text { u3 } & 0.57^{8} 5 & 0.7488 & 0.1348 & 3.4527 \\ \text { u4 } & 5.9501 & 0.0510 & -0.8212 & 3.397^{8}\end{array}$

ARCH-LM TEST with 4 lags

$\begin{array}{lllll}\text { variable } & \text { teststat } & \mathrm{p}-\text { Value }\left(\mathrm{Chi}^{\wedge} 2\right) & \text { F stat } & \mathrm{p}-\text { Value(F) } \\ \text { u1 } & 4.8248 & 0.3057 & 1.3475 & 0.2688 \\ \text { u2 } & 4.4002 & 0.3545 & 1.2164 & 0.3186 \\ \text { u3 } & 0.6793 & 0.95^{3} 9 & 0.1724 & 0.95^{13} \\ \text { u4 }_{4} & 1.9726 & 0.7408 & 0.515^{2} & 0.7249\end{array}$

MULTIVARIATE ARCH-LM TEST with 4 lags

VARCHLM test statistic: $\quad 426.4,672$

p-value (chi^2): $\quad 0.1738$

Degrees of freedom: $\quad 4,00.0000$ 
